\title{
Verbal and pictorial similarity in recognition of pictures*
}

\author{
SARA WYANT, Claremont Graduate School, Pomona, California 91711 \\ WILLIAM P. BANKS + , Pomona College, Claremont, California 91711 \\ DALE BERGER, Claremont Graduate School, Claremont, California 91711 \\ and \\ PAUL W. WRIGHT††, Pomona College, Claremont, California 91711
}

This experiment explored the role of pictorial and verbal coding in memory or pictures. Ss viewed slides for either 3 or $10 \mathrm{sec}$ each. One hour after viewing hey were given a two-alternative forced-choice recognition test. Test pairs had jeen previously rated on separate scales for visual similarity and for the ease vith which the difference between them could be verbally described. Verbal lescribability predicted recognition best after both $3-$ and $10-\sec$ viewing times. At the $10-\mathrm{sec}$ presentation rate, recognition accuracy was unrelated to rated isual similarity, but at the 3-sec rate, errors increased slightly as visual similarity ncreased. Memory for pictures is mediated at least in part by verbal coding, but nemory storage itself is probably not exclusively verbal. Visual features of jictures memorized by Ss may be selected on the basis of verbal descriptions of ihe pictures.

Our capacity for remembering somplex, meaningful, pictorial stimuli las been shown to be very great 'Haber, 1970; Nickerson, 1965; Shepard, 1967; Standing, Conezio, \& Haber, 1970). Shepard presented Ss with 612 color pictures and tested them using a two-alternative forced-choice paradigm with 68 pictures from the presentation series paired with 68 new pictures. Correct recognition for pictures was $96.7 \%$, while it was only $88.4 \%$ for words and $39 \%$ for sentences in identical recognition tasks using visually presented words and sentences as timuli. Nickerson found correct recognition to be $95 \%$ on a yes-no test for Ss who had initially seen 200 pictures.

Haber and Standing (see Haber, 1970, and Standing et al, 1970) extended Shepard's study by presenting $S$ with a presentation series of 2,560 slides viewed for 10 sec each. On a forced-choice recognition test of 280 pairs, Ss correctly identified 85\%-95\%. Haber (1970) concluded

*This research was supported in part by a Vational Science Foundation grant GU4039) to the Claremont Graduate School a Pomona College Faculty Research trant to $W$. P. Banks, and a bequest to $P$. W. Wright by Mrs. Sidney Gleason in memory of her late son. Edward $R$. Gleason. This esearch formed part of S. Wyant's Marter's lissertation at the Claremont Graduate School and was presented by $P$. W. Wright at the April 1971 meetings of the Western Psychological Association. The generous rsistance of Jon Maaske in photorraphin and developing the pictures is greatly ppreciated.

+ Send requests for reprints to William $P$. Banks, Department of Psychology, Pomona Colleze, Claremont, California 91711.

HNow at the University of San Diego School of Law. from the impressive demonstration of Ss' capacity for pictorial recognition that memory for pictures is essentially perfect and that there are separate memory processes for storing verbal and pictorial material. He suggested that images of pictures are received and stored in pictorial form without use of words, labels, or names. Presumably, Haber came to this conclusion because recognition of words and sentences is worse than that for pictures (cf. Shepard, 1967) and verbal coding thus could not underlie pictorial recognition.

Some researchers have suggested that perceptual memory is mediated by verbal coding (e.g., Glanzer \& Clark, 1964). Impressive as pictoriai recognition is, verbal coding has not been eliminated as a possible mechanism for storing pictorial information. If Ss verbally coded and retained a single, most salient feature of each picture presented for viewing, recognition scores could be good if distractors in the test series were not similar to the pictures previously viewed. Shepard, in fact, chose his pictures on the basis of salient features that would be memorable and not similar or confusable. Haber's randomly compiled test series is probably comparable in most cases to Shepard's in dissimilarity of distractors and target pictures.

It is possible to assess the relative importance of verbal coding and pictorial storage in memory for pictures. If memory for pictures is based on pictorial storage, visual similarity between targets and distractors in recognition tests should reduce recognition accuracy. If memory for pictures is mediated by verbal coding, recognition should decline as the verbal code assigned to the target becomes less efficient at distinguishing it from distractors. Dallett, Wilcox, and D'Andrea (1968) manipulated both of these variables simultaneously by using a test series in which distractors and targets could be described with the same code and were also visually similar. They found recognition to be $60 \%-70 \%$, even though only 40 pictures were in the learned set. Because they used a yes-no paradigm, it is difficult to compare their results with Haber's or Shepard's, but the poor recognition they found is probably the result of one or both of the similarity variables they used.

The present experiment attempts to separate visual similarity and verbal describability to determine which factor is more significant in recognition memory for pictures. The strategy of the experiment was to generate test pairs for two-alternative forced-choice recognition that provided an orthogonal combination of visual similarity and verbal codability. The pairs used for recognition testing were selected from a large set of pairs previously rated on these two variables by a different group of $S s$ from the one which performed in the memory experiment. Presentation time during leaming was also varied to assess differential effects of time on the two variables in recognition.

\section{METHOD}

Materials

A collection of 1,676 color and black-and-white photographic slides from a variety of sources was assembled. Subject matter covered a wide range including landscapes, family scenes, crowd scenes, buildings, sculptures, paintings, single objects, and histology slides (tissues and cells). From these slides, 650 pairs were selected and presented to five Pomona College students who rated each pair on two separate scales: (1) verbal describability ("How easy would it be to describe the difference between these two slides?") and (2) visual similarity ("How similar do these two slides look?"). Raters saw slide pairs for $10 \mathrm{sec}$ and were given as much time as they needed between presentations to complete their ratings. Ratings on both scales were from 1 to 7 , where 1 was easiest to describe on the describability scale and most similar on the similarity scale. Two hundred and nineteen of the 650 pairs were sorted into a 3 by 3 matrix according to ratings on the two scales (see Table 1 for examples). The most desirable category was limited to slides with an average rating of 1.0-2.2; the intermediate category contained slides rated from 3.2-4.8; and the hardest to 
Table 1

Stimuhus Categories, Descriptions of Sample Stimulus Pairs Falling into Each CroseClasaification, Number of Patrs in Each Crose-Classification, and Mean Percent of Correct Recosnition for the 3Sec Group and 10-Sec Group

\begin{tabular}{|c|c|c|c|c|}
\hline \multirow{2}{*}{$\begin{array}{c}\text { Verbal } \\
\text { Category }\end{array}$} & \multicolumn{3}{|c|}{ Visual Category } & \\
\hline & Visually Dissimilar & Intermediate & Visually Similar & \\
\hline $\begin{array}{l}\text { Easy to } \\
\text { Deseribe } \\
\text { Verbally } \\
10 \mathrm{sec} \\
3 \mathrm{sec}\end{array}$ & $\begin{array}{l}\text { An office building in } \\
\text { one picture and a } \\
\text { camping scene in the } \\
\text { other. (36 Pairs) } \\
\qquad \begin{array}{c}90.74 \\
93.75\end{array}\end{array}$ & $\begin{array}{l}\text { Two pictures of liv- } \\
\text { ing room scenes with } \\
\text { different familles in } \\
\text { each picture. } \\
\text { (30 Pairs) } \\
90.55 \\
81.67\end{array}$ & $\begin{array}{l}\text { A picture of a farm } \\
\text { scene and an identi- } \\
\text { cal picture with a twis } \\
\text { across one corner. } \\
\text { (29 Pairs) } \\
93.10 \\
83.62\end{array}$ & $\begin{array}{l}91.46 \\
86.35\end{array}$ \\
\hline $\begin{array}{l}\text { Inter: } \\
\text { mediate }\end{array}$ & $\begin{array}{l}\text { Two pictures of a } \\
\text { street in a city- } \\
\text { completely different } \\
\text { streets and buildings } \\
\text { in each picture. } \\
\text { ( } 31 \text { Pairs) } \\
\qquad 82.26 \\
81.45\end{array}$ & $\begin{array}{l}\text { Two pictures of chil- } \\
\text { dren playing in a } \\
\text { park. } \quad(30 \text { Pairs) }\end{array}$ & $\begin{array}{l}\text { A picture of a water- } \\
\text { sier with boats in } \\
\text { the background and } \\
\text { a picture of the same } \\
\text { waterkier with the } \\
\text { shore in the back- } \\
\text { pround. ( } 30 \text { Pairs) } \\
74.44 \\
66.67\end{array}$ & $\begin{array}{l}77.23 \\
76.87\end{array}$ \\
\hline $\begin{array}{l}\text { Difficult } \\
\text { to Des } \\
\text { cribe } \\
\text { Verbally } \\
10 \text { Sec } \\
3 \text { Sec }\end{array}$ & $\begin{array}{l}\text { Two cross-sections } \\
\text { of different tissues } \\
\text { with different strains } \\
\text { at different enlarge- } \\
\text { ments. (14 Pairs) } \\
\qquad \begin{array}{l}4.62 \\
64.42\end{array}\end{array}$ & $\begin{array}{l}\text { Two different close- } \\
\text { up pictures of dif- } \\
\text { ferent flowers. } \\
\text { ( } 9 \text { Pairs) }\end{array}$ & $\begin{array}{l}\text { Two pictures of the } \\
\text { same leaves on a } \\
\text { sidewalk with the } \\
\text { leaves scattered dif- } \\
\text { ferently in the two } \\
\text { pictures. (10 Pairs) } \\
58.33 \\
50.00\end{array}$ & $\begin{array}{l}53.83 \\
56.66\end{array}$ \\
\hline $\begin{array}{r}10 \mathrm{Sec} \\
3 \mathrm{Sec}\end{array}$ & $\begin{array}{l}73.54 \\
79.87\end{array}$ & $\begin{array}{l}73.70 \\
73.24\end{array}$ & $\begin{array}{l}75.29 \\
66.76\end{array}$ & \\
\hline
\end{tabular}

describe category contained slides rated 6.0-7.0. The three categories of visual similarity were based on the same numerical boundaries. The categories were made noncontiguous to assure that the classes would be distinct.

A series of 960 slides was constructed for presentation to $\mathrm{Ss}$ in the learning experiment. One slide from each of the 219 test pairs was included in the presentation series, mixed with 741 other slides randomly selected from the pool of unused and rejected pairs of slides.

\section{Procedure}

Each $S$ in the 10-sec group viewed the presentation series of 960 slides for 10 sec each and those in the 3 -sec group viewed them for $3 \mathrm{sec}$, with about $1 \mathrm{sec}$ between slides for both groups. The Ss were informed that later they would be asked to recognize the slides they saw. Total presentation time was approximately $3 \mathrm{~h}$ for the 10 -sec group and $1.25 \mathrm{~h}$ for the 3 -sec group. A 15-min break divided the experiment into two 90 -min sessions for the 10-sec group. The 3-sec group had no break. Target slides (those to be presented in the test later) were not among the first or the last $\mathbf{4 0}$ pictures shown in any experimental session. At the end of the presentation series, Ss were given a 1-h break. The Ss then viewed each test pair and marked left or right on an answer sheet to indicate similarity increased, with an $F(1,16)=10.1, p<.01$. The individual Ss' overall percent correct recognition ranged from $71.7 \%$ to $86.7 \%$ in the 10 -sec group and from $72.6 \%$ to $92.8 \%$ in the $3-\mathrm{sec}$ group.

\section{DISCUSSION}

As the rated difficulty of describing the difference between a pair of slides increases, recognition decreases. This finding holds for both presentation rates. The role of visual similarity in recognition is less straightforward. There is no evidence for visual confusion at the 10 -rec presentation rate, but there is at the 3 -sec rate. $B y$ the logic behind this study, the obvious interpretation of this result is that verbal coding operated at both presentation rates but that some purely visual coding of the pictures was used at the 3 -sec rate. It seems reasonable to suppose, as Tversky (1969) has suggested, that memory for pictures utilizes both a pictorial and a verbal code. Verbal coding could be sufficiently more detailed than pictorial coding so that, given adequate time for the construction of verbal codes, the verbal mechanism overrides any pictorial coding that occurs. But, when time is at a premium or verbal coding is otherwise disrupted, reliance is placed on the quicker pictorial code. Since verbal describability is still a significant factor at the shorter time, a complete switch seems unlikely.

The visual similarity effect at the 3-sec rate might, however, be explained in terms of verbal coding alone. If verbal coding proceeds from generalities to details or from more to less visually salient features while the $S$ is viewing a picture, reducing viewing time would produce less detailed verbal codes. Thus, at the 3 -sec rate the gross differences between visually dissimilar slides would be better encoded than finer, but often more verbally useful, differences.

A difference between the groups that is difficult to control is the overall elapsed time between viewing and testing. The elapsed time between the first presentation and first test was approximately $2 \mathrm{~h}$ longer for the 10-sec group than for the 3-sec group. To determine the effects of elapsed time, errors on slides presented in the first half of the series were compared with errors on slides in the last half of the series. In both the $3-\mathrm{sec}$ and 10 -sec groups, no significant differences were found.

Does the rating and classification system used in this experiment separate visual and verbal discriminability? The instructions given the raters were designed, of course, to separate the visual and 
verbal factors, but it remains to be shown that the raters did follow the instructions. Whatever the raters did, however, they seemed to agree with each other fairly well. (Unfortunately, interrater reliabilities were not computed. The best that can be said is that those who tabulated the data felt that agreement was good.) The raters also found the ratings easy to make it seems, because they did it rapidly and with a minimum of complaints. Furthermore, the face validity of their ratings is good. The sample slide pairs described in Table 1 are meant to illustrate the face validity of the rating categories. Finally, the pattern of results of the experiment indicates that the two rating scales measure different things, whatever these things are. If the visual and verbal classifications are confounded, they should have shown similar effects but, at least at the $10-\mathrm{sec}$ rate, their results were quite different.

The experiment, because it used histology slides, samples a range of pictures more diverse and unusual than was used in previous investigations of pictorial memory. It might be argued, therefore, that the results are forced by the unfamiliar pictures or are not applicable to situations where more ordinary pictures are recognized. The results, however, would be little altered if the histology slides were removed from consideration. Although most of them were in the three difficult-to-describe cells, they appeared in all nine cells of the cross-classification. Mean errors for pairs of histology slides were in no case significantly different from the mean errors for the cells in which they fell. In fact, in seven of the nine cells, there were proportionally fewer errors on histology slides than for the cell as a whole.

The rated differential verbal describability of slide pairs predicts memory-based discrimination best at both presentation rates, but it is not necessary to conclude from this that memory for pictures relies on a stored verbal code. The raters may have used the verbal scale to rate the discriminability given by the most describable features of the pictures. These would be visual features, but they would be selected on the basis of the ease of identifying and naming them. Storage, then, might be of visual features, but visual features selected on the basis of the requirements of verbal description. It seems highly unlikely that there is no capacity at all for purely visual memory. The capacity for remembering what is seen must exist for preverbal children and nonverbal animals. It is improbable that man loses this capacity with the development of language, but verbal coding or verbally based strategies in selecting what is to be stored may make it more efficient.

\section{REFERENCES}

DALLETT, K. WILCOX, S. \& D'ANDREA, L. Picture memory experiments. Journal of Experimental Psychology, 1968, 76, 312-320.

DALLETT: K., \& WILCOX, S. Remembering pictures versus remembering descriptions. Psychonomic Science, 1968, 11, 139-140.

GLANZER, M., \& CLARK, H. The verbal-loop hypothesis: Conventional figures. American Journal of Psychology, $1964,77,621-626$.

HABER, N. How we remember what we see. Scientific American, 1970, 222, 104-112. KIRK. E. Experimental design procedures for the behavioral sciences. Belmont, Calif: Brooks/Cole, 1968.

NICKERSON, R. S. Short-term memory for complex meaningful visual configurations: $A$ demonstration of capacity. Canadian Journal of Psychology, 1965, 19, 155.

POTTER, M., \& LEVY, E. Recognition memory for a rapid sequence of pictures. Journal of Experimental Psychology, $1969,8,10-15$.

SHEPARD, N. Recognition memory for words, sentences, and pictures. Journal of Verbal \& Learning Behavior, 1967, 6 . 156-163.

STANDING, L., CONEZIO, J., \& HABER, R. N. Perception and memory for pictures: Single-trial learning of 2500 visual stimuli. Psychonomic Science, $1970,19,73-74$.

TVERSKY, B. Pictorial and verbal encoding in a short-term memory task. Perception \& Psychophysics, 1969, 6, 225-233.

(Accepted for publication April 14, 1972.) 